International Journal on Social Science, Economics and Art, 11 (4) (2022) 150-164

\title{
Reviewing the Challenging Factors of Survival During COVID 19 Uncertainty
}

Tahreem Noor

University of Hail, Arab Saudi

\begin{tabular}{|c|c|}
\hline Article Info & ABSTRACT \\
\hline Article history: & \multirow{7}{*}{$\begin{array}{l}\text { Social media /online platforms are particularly important in times of } \\
\text { crisis, as they are a vital channel for providing and ensuring access to } \\
\text { information about products and services in an efficient manner. In a } \\
\text { time of crisis and economic down turn, businesses usually begin to cut } \\
\text { expenses, while they reduce their marketing budget; the key question is } \\
\text { how business make an effort to be visible for their customers and how } \\
\text { they react to uncertain situation. This research will review the existing } \\
\text { literature to lays out the theoretical foundations to extract the } \\
\text { 'happenings' and issues of marketing during the crises and provide } \\
\text { some evidence of the global companies. It would suggest how businesses } \\
\text { can better prepare themselves so that they can be more resilient to } \\
\text { overcome the uncertainty and more agile to cope with these challenges } \\
\text { in future. Despite the perennial need to understand and manage } \\
\text { uncertainty in business, there is lack of data that highlight on the } \\
\text { corporate marketing communication approaches for their customers. } \\
\text { The findings of this research suggested that, during any crisis or high } \\
\text { uncertainty, businesses must prepare themselves to alter their corporate } \\
\text { marketing communication approaches and strategies, for their } \\
\text { customers. This will reduce stereotype attitude, confusion, backlash or } \\
\text { any negative connotation. To stay afloat in a highly competitive digital } \\
\text { world, businesses can focus on clarity and tone of the communication } \\
\text { message, align their operational and strategic process and it outcomes. } \\
\text { Be vigilant by identifying the vulnerability and refocusing on brand } \\
\text { values. Gather intelligent information using analytical tools - internal } \\
\text { and external information. Devise appropriate reactive and proactive } \\
\text { responsive strategies to survive in uncertain situation. }\end{array}$} \\
\hline Received: Dec 01, 2021 & \\
\hline Revised: Dec 24, 2021 & \\
\hline Accepted: Jan o9, 2022 & \\
\hline Keywords: & \\
\hline $\begin{array}{l}\text { Social Media; } \\
\text { Brand; } \\
\text { Marketing; }\end{array}$ & \\
\hline Coronavirus. & \\
\hline
\end{tabular}

This is an open access article under the CC BY-NC license.

\section{Corresponding Author:}

Tahreem Noor

University of Hail, Arab Saudi

College of Dentistry, Hail 55475, Arab Saudi

Email: tahrimnoor@hotmail.com

\section{INTRODUCTION}

Pandemic such as Coronavirus (COVID-19) precipitated business and consumer behavior on a drastic and massive scale. Business are overwhelmed with unpredictable curfew measures by the government, faced with unmapped strategy routes and competing challenges as they have to navigate and survive in the COVID-19 pandemic. To maneuver and to survive in such uncertain situation, businesses have modified their consumer policies in response to COVID-19: e.g. offering free shipping, no-contact 
delivery or pick-up services, extending time-periods for change-of-mind returns or waiving cancellation fees (OECD, 2020). Businesses have cut down advertisement budget through traditional medium and start focusing on web display ads, social media channels, and online corporate video in this lockdown. However, the challenge for companies is to utilize online channels and increase reputation as well as favorable consumer brand association connect with customers with right product and service experience (Buil et al., 2013).

Due to restrictions on physical interactions, consumers' lifestyle changed overnight, online platforms become a vital source for shopping and obtaining information. Therefore, consumers have indicated that they want information about service adjustments and updates, including store closures or new online options (Ives, 2020).

During COVID crisis, example of some companies initiatives are listed who offer related products and services through online channels / marketing, such as

a) Discounts on products: Amazon offer its audio books free for consumers and IKEA UAE offer a heavy discount on study desks and chairs, because of work or study from home (Allison, 2020).

b) Collaborative effort for more sale: Haagen-Dazs ice cream via collaboration with Amazon prime send a special weekly code that allow ordering ice cream flavor of the week while streaming movies (Campaign live, 2020).

c) Product customization for COVID: LUSH $100 \%$ vegetarian, handmade cosmetics and soaps. They created ' 30 -Second Soap', a self-timing soap designed to dissolve away after 30 seconds, precisely consumer need to clean their hands safely (COVID innovation, 2020, 11 June).

d) Positive messages through packaging: Colombian food company 'Ramo' modifies the packaging of its product, to give a message of hope amid COVID. Their sliced bread 'Unidos', showcased 'Together', 'Hugs' and 'Courage' on its product packaging (Semana.com).

e) Featuring the heroes from the frontline of COVID-19: PepsiCo China initiated a campaign of showing respect of frontline by featuring the heroes from the frontline of COVID-19 on the Pepsican.

f) Inviting kids for healthy ideas: To deal with kids' boredom, US based Nature Bakery (glutenfree, dairy-free, nut-free and Non-GMO) created 10o+ activities, which parents can do with kids. It also encourage kids to share their ideas for snack-sized adventure on their website to win free snacks (naturesbakery.com).

g) Engaging consumers to create an ad from home: Doritos launched marketing approach, asking their fans to create its first TV commercial by "Crash from Home," in the pandemic, with the winning amount of $\$ 150,000$ (Fritolay website).

h) Unconventional solution: For unemployed people in Vietnam, setup of Rice ATMs that dispense free rice from 8 a.m. to 5 p.m. each day (CNN, 2020) and in Dubai, car fuel service through mini tankers delivered at consumer place during lockdown (Khamis, 2020).

i) Concern and support for older consumers: Sainsbury UK retail supermarket responded swiftly to the development of the epidemic, prioritizing online grocery slots for elderly, disabled and vulnerable people.

j) Social distancing in a fun and playful way: Burger King in Germany tests funny giant hats/ crowns to ensure six feet away to enforce rule of distancing, safety and hygiene (Design boom, 2020).

k) Social responsible facemask: Fine Guard mask Dubai created the campaign 'Waste Can Mask Our Future', it all started with a question, 'Did you know disposable face masks don't degrade? Thus polluting environment". The idea was to make people aware of the impact disposable masks on environment, and Fine Guard identify the environmental issue and created reusable and washable masks (fineguard.me).

1) Support NHS and medical companies: Loui Vuitton made and distributed hand sanitizer to health authorities - likewise Ford and General Motors resolve the shortage of ventilators by helping medical device companies to scale up production of the critical equipment (BBC news, 2020; O'kane 2020). 
m) Digital experiential marketing: PepsiCo Malaysia host a music concert using Augmented Reality technology to promote Pepsi Black Raspberry, positioned as a zero-calorie drink.

In existing literature, there is an attempt to offer approaches and methods to survive business in ambiguous and unstable environment, however, yet no comprehensive framework exist that identify the key essential factors to survive and manage uncertainty (Rigby et al., 2020). This makes it difficult for business managers to manage uncertainty and develop appropriate strategies in ongoing COVID-19 pandemic. This paper review existing literature to extract challenging and survival factors of marketing and branding during COVID crisis and uncertainty. The research concludes with some implications for business managers and directions for future research.

\section{RESEARCH METHOD}

In the last few years, the world faces outbreaks of infections (SARS, MERS, Ebola, Zika, etc.), but the global impact of COVID-19 could lead businesses to rethink how they can prepare for a sudden crisis in future. Considering that, this research set a research question: What factors business should be consider to manage and survive the crisis in future?

To address the research question and objective, we reviewed around 140 researches and articles related to brand crisis, brand survival, online marketing challenges during pandemic, consumer frustrations or concerns and interconnected business issues. Furthermore, online news articles and survey reports were also included to identify the 'marketing happenings' of global companies'. Therefore, the nature of this research is qualitative inductive as based on the 'happening' identified from the literature, framework of five points suggested (Fig. 1). Literature consistently assert that, in dynamic global environment and in the presence of emerging social media, sudden crisis and vulnerability can threaten organization reputation and relationship with stakeholders (Coombs \& Holladay, 2012). In this crisis broadly, identified that even established businesses made some mistakes (dis-connectivity at strategic level, operational process deficiency, quick fix /random solutions and communication gaps). Consumer perceived COVID advertisements and business claims over rhetoric, over-excitement, tone deaf, misleading, taking advantage of situation and not focus on contribution. This research guide further to reduce backlash, cynical attitude, negative word of mouth or switching. Existing research either focusing on one or two of the factors, there is a gap in an existing literature that indicate the need of all five factors during uncertain situation (clear communication, overview/review their process and measure the outcome, vigilant identifying vulnerability, intelligent information, devise reactive /proactive responsive strategies).

\section{RESULTS AND DISCUSSIONS}

3.1. Learning orientation and agility

Literature suggested that a strong learning orientation might be more important than a strong market orientation during crisis specifically (Lukas \& Ferrell, 200o). Concerning learning orientation, 'strategic' and 'operational' agility may assist in transforming and making them resilient to deal with current or potential weakness and threats faster than its competitor. At strategic level, each department (customer service, supply chain, employees, IT, resources) should be responsible for ensuring the protection of the brand, and identifying unexpected risks and shocks inside and outside the business environment (Grundey, 2009; Tilman \& Jacoby, 2019; Al Shehab, 2020). Whereas, operational agility require openness and commitment to learning, offer quality enhancement of its existing products / services better, faster, cheaper for existing customers, and ability to create new knowledge (Denning, 2018).

\subsection{Alternative solutions during crisis - Operational Agility}

Despite the rhetoric claim, that 'we as an organization are agile', does not make it so.....too many organizations did not have the capabilities to respond the uncertainty of COVID (Worley and Jules, 2020). In this crisis, we have seen a known brand Wendy's example for not planning the substitute of their supply chain thus it might affect their reputation. Wendy's pull burgers from the menu due to fresh beef shortages across the US, and not willing to switch to frozen beef. Wendy's emphasized and claim strongly that they never use frozen beef in marketing. On social media, Wendy's has even mocked 
McDonald's for selling items made with frozen beef (Business insider, 2020). Around the same time, McDonald announced boosting their marketing spend by \$10o million, it might excite some of Wendy's customers to make the switch (Tenet Research agency, 2020).

\subsection{Use of advanced analytics}

To accurately forecast and to track changes in consumer demand, identifying potential supply-chain disruptions, offering support workers at-risk, a report suggested that advanced analytics and the Internet of Things (IoT) could improve business agile ability (Mckinsey report, 2020). To monitor stock levels, to adapt to customers' changing needs and identify categories where additional stock is required, Carrefour, a retail hypermarket chain that operates in 38 countries, used advanced analytics (Khamis, 2020). $\mathrm{O}_{2}$ British telecommunications services provider, initiated internet of things (IoT) for COVID safeguarding solutions at workplace (thermal imaging tablet, a handheld thermal imaging scanner, and social distancing room management). The thermal imaging tablet is a sensing tablet, read surface body temperature from a distance of one meter. The tablet also ensure a contactless check-in, visitors required to use a unique $\mathrm{QR}$ code to confirm their attendance. To manage social distancing, this solution monitor people count and occupancy status, and digital display green or red, depending on whether it is safe to enter an area (Stewart, 2020).

\subsection{Short-term sale as an alternative solution during crisis}

Kamber (2002) indicated that during a recession change in advertising spending has a positive and statistically significant relationship to short-term sales. In COVID, due to travel restriction, airline realize the opportunity of short term marketing by targeting frequent travelers and nostalgic flyers, Blue Airlines (Romanian low-cost airline) encourage customers to order their signature in-flight cheese snacks Stroopwafels, Biscoffs trays via its online produce marketplace for \$2.99 each (Eater.com). Also, AirAsia (Thailand low-cost airline) offer in-flight popular choice 'Boba Tea' (Thai Pearl Tea), stir-fried yentafo and teriyaki chicken and rice to people stuck at home through delivery services (AirAsia.com). Similarly, alternative solution was thought of for shooting campaign in COVID, Czech carmaker Škoda releases campaign 'creativity beats crisis', entirely ad shot from home using miniatures of Škoda SUVs cars (COVID innovation, 2020). It indicates that in short term solutions, companies take control of process or things that are easily changeable, closely monitored and adjusted as needed, such as alternative options of sales, digital promotion and social media advertising.

\subsection{Alignment of corporate strategy, marketing and responsive strategies during crisis -}

\section{Strategic Agility}

a. Scanning, quantify risk and call on action

Researchers also believes that companies need to pay attention to aligning strategy and implementation of a plan, to deliver a strong brand experience for customers (Hough et al., 2008; Shrivastav \& Thomas, 2010). Tension will increases if mismatch or gap exist between the two, resulting in the failure or loss (Sull, 2003). Businesses are supposed to identify the stages of vulnerability/risk from initiating to implementation (Frei et al., 2008):

a) Discovery Time: This period is the earliest time of vulnerability, will have limited information, thus also called black risk.

b) Exploit Time: This period exposed vulnerability and require close monitoring of activities to understand the ground issues.

c) Disclosure Time: This stage publicly announced the risk and aimed at mitigating the risk exposure.

d) Patch Time: This period is consider as white risk in which companies re-mediate and fix existing vulnerabilities.

To realign / revisit the performance with efficiency, it is essential to identify the emerging risk by 'frequent' and 'extensive' scanning, quantify threats by 'risk mapping by category' and 'risk ranking by frequency and severity' and 'call on action', if adequately reported could take actions and decisions accordingly (Kumar et al, 2001; Shrivastav \& Thomas, 2010; Waller et al., 2014).

Internal information will assist to evaluate the issues and risk at corporate, product and service level (Strandholm \& Kumar, 2003). However, lack of information and data search skills may result in 
high operating cost (Cheuk, 2002; O'Sullivan 2002) and strategic uncertainty will remain challenged if organizations are

a) unable to determine the type of information needed

b) unable to obtain and exploit information from sources

c) unable to retrieve needed information

d) limited information of sharing with other employees

The corona crisis has revealed that disinformation poses serious threats to consumer trust in institutions, societal security and stability (Veriter, 2020). Furthermore, to exploit and to explore new information, company need to develop appropriate processes and skills (March, 1991). Concerning critical situation, insight information can be obtained from technical staff specifically, business solution architect, mobile app developer, data builder software, social media specialist, digital content specialist and crisis manager and shared with relevant department to devise appropriate action and strategy.

b. Connectivity of short-term approach and responsive strategies with corporate goals

Instead, to seek how their short-term advertisements can affect their corporate strategy and reputation in the long run, in such worldly crisis, business are taking an advantage of an opportunity, and battling over advertising to increase their market shares, with an intention to influence consumer behavior by lowering the reputation of other brand product.

Hygiene brands in India, Unilever (Lifebuoy) took Reckitt Benckiser (Dettol) to court over a hand wash advertisement allegedly mocking and attempted to belittle the effectiveness of Lifebuoy soap hand washing in preventing the spread of coronavirus. In Dettol advertisement, a doctor asks patients to keep away from a soap (shown as a red bar) that resembles the configuration of Lifebuoy soaps. Unilever (Lifebuoy) maintained that their red bar shape was clearly recognizable in Reckitt Benckiser (Dettol) advertisement. Unilever (Lifebuoy) approached the court for seeking damage of reputation; the court suspended the use of that advertisement (Ranga and Tandon, 2020). During a crisis, businesses should offer value and think about the contribution and its relevance with their corporate strategy, rather than on consumer conversion or selling the product.

Furthermore, the withdrawal of the product/communication campaigns will face reduction in efficiency of brand investment in marketing, reputation damage and process failure (Kalaignanam et al., 2013; Assiouras et al., 2013). However, Souiden \& Pons (2009) have concluded that a significant positive image will be develop, if company voluntarily recall the defect campaign then denial of it. Denial (refusing to accept) in situational crisis communication framework will be effective, if outrage is there but firm is not connected to that crisis, thereby firm must disclose all related information to calm down the anger (COOMBS, 2007).

Zhu et al. (2017) believed that apology is one of the highest level of response strategy since brands can send either the deepest and sincerest apology to affected customers or apology with compensation to minimize public irritation. Claeys and Cauberghe (2014) study has proven the effect of organizational acknowledge statement in reducing public's offensiveness and establishing a new favorable image (Kim \& Atkinson, 2014). Whereas "Silence strategy - no comment" is categorized as lowest level of organizational involvement and responsibility towards solving crisis (Vafeiadis et al., 2019).

\subsection{Consideration of employees' perspectives}

Employees' perspectives are also critical, to sustain brand promise and to provide further insights into customers. Flammer and Kacperczyk (2015) hypothesize that stakeholder-friendly view in consumerfocused organization relieves consumers, employees, and managers from myopic behavior and helps spark innovation. Specifically, businesses need to encourage lower-level employees, social media handlers, and online customer service representatives to share actual ground issues. Instead of considering employee suggestion in such unpredictable situation, taking severe action is not solution: such as Trader Joe fired an employee who suggested three-strike policy to deal with those customers who are not wearing mask in store despite of several request.

Moreover, in Canada grocery retailers rolled back hourly 'Hero Pay', faced severe backlash from front-line retail workers, as they consider it a sign of respect and appreciation from retailers. Therefore, 
if failed to recognize employees as important stakeholders, it can result in the failure to provide the ethics of justice and care (Xu \& Li, 2012).

\subsection{Using of rational evaluative criteria instead of subjective approach}

Most firms do not even attempt to assess uncertainty or they may rely on unstructured and subjective opinion/ judgement or assessment methods of managers (Eduardsen \& Marinova, 2020). Perhaps the most common mistake in framing new challenges is evaluation criteria, Sull (2003) suggested to generating all possible ideas and options and then develop criteria later. In this COVID, Red Bull motorsport advisor proposed an idea to organise a 'Corona Camp' for his team's Formula-1 race drivers so they would deliberately get infected with COVID-19 and become immune. Redbull motorsport advisor believes that this way race driver would be prepared and ready for tough championship once it starts, though proposal was turn down (The Guardian, 30 March 2020).

\subsection{Follow consumer-buying behavior and obtain information}

Further literature also assert that to reduce the unpredictability, to increase stakeholder sense of empowerment as well as to ensure the uniqueness of the brand/product, orientation of customers, competitor, inter-functional coordination, dissemination of information deem necessary (Miller, 1989; Narver \& Slater, 1990; Martinelli \& Briggs, 1998; Rowan, 1996). It require managers to regular scan, monitor, make decision, and evaluate to manage communication and information related issues (Heath \& Palenchar, 2009; Larkin \& Regester, 2005). Major shift have been noticed across all aspects of the consumer's life - daily challenges, buying behaviors and emotional mindsets. Consumers have fear for their health, family, future, financial security, if not handle well, consumers will remain frustrated, confused and unsure. Considering that, businesses should dig deeper into consumer emotions, purchasing behaviors including identify frustrations and personality type- optimists and pessimist and address accordingly.

a) Value, price/promotion and convenience were the top three reasons for shopping for consumers across all countries (Arora et al, 2021).

b) $92 \%$ United Arab Emirates and Saudi Arabia consumers notice change in shopping habits, they shifted to online shopping. $61 \%$ of consumers focus on the brand they have purchased previously (Khamis, 2020).

c) Indian and Chinese consumers research about the brand and product choices before buying, in comparison to France and Germany consumers (Arora et al, 2021).

d) In times of crisis, further noted that consumer prefer buying familiar and trusted brands specifically European consumers, whereas consumer in France and Spain favor local businesses in compare to big brands (Mckinsey report 2020). Therefore, businesses are paying more attention to the origin of products and supporting local (Allison 2020).

e) European consumers are less optimistic about future and economy, so business need consider and share positive news that can boost their hope (Mckinsey, 2020).

3.9. Consumer concern over safety during online transactions and shopping

From the current COVID experiences it is found that, cyber resilience approaches should be handle well in future crisis or in uncertain situation. Consumers would not make initial and repeated buying decision if customer perceived risks (financial, functional, physical, psychological, or social risks) (Boksberger \& Graig-Smith, 2006). In US more than 22, ooo consumer complaints about COVID-19 online shopping fraud to the Federal Trade Commission (FTC) between January - April 2020, amounting to over USD 22 million in consumer losses. Online shopping scammers send a fraudulent online message offering COVID-19 medical packages and relief payments or fake COVID charity scam (OECD, 2020). Some phishing scams under false pretence claiming to be from health or disease control organizations like the World Health Organization enticed consumers to share their personal information such as passwords, accounts and other payment information, in order to steal money.

To relieve from perceiving risk consumer rely on word of mouth, past experience, information search, prefer reputable retailer, brand reassurance through marketing and service (Lacey et al. 2009). 


\subsection{Consumer get overwhelmed with social media communication during crisis}

Consumers are isolated, lonely, bored, and missing their normal life-effected them emotionally, physically, financially. But in such disruption and loss every COVID-19 commercial or ad seem the samesimply acknowledging the situation or express concern about uncertainty, stay safe stay home, and reminding that we as business are all inherently vulnerable. Although consumer priorities have become centered on the most basic needs, demand for grocery, hygiene and cleaning items, but still business need to realize how they are connecting with overwhelmed and stressed out consumers. Indeed, it is a challenge with social media to make a brand unique on dimensions that are relevant and welcomed by consumers (de Chernatony \& McDonald, 1999).

Online advertisements consider cheaper in compare to other media platforms as businesses cut ad budgets of traditional advertisements and consumers spend more of their time online during the pandemic. Businesses can actively seek out conversations with customers via comments, chat inbox, polls, surveys, and other engagement features on social media. Remarketing to those who have liked, commented on, shared, or interacted with Facebook and Instagram business page, watched videos or post. Passively note the pattern of questions, emerging problems, from comments and chat discussion on social media platforms. From the data, businesses should identify any specific relief points (refund or reschedule) for those who may experience stress or hardship during these times. Employees working from home juggle childcare and household responsibilities, so considering that posting ads at different times during the day and analyze results with social media analytics will be useful.

Furthermore, eye tracking, facial recognition, virtual reality technology has the potential to measure emotions based on consumer neuroscience and to understand the effectiveness of advertisement (Otamendi \& Sutil, 2020). Frozen food Captain Birds Eye realize that their sales start declining and they battled with lack of trust in the products. To revitalize consumer perceptions, they conducted neuro testing to understand consumer memory structure and strong associations with the Captain. Through neuro testing, they also found that if too much the product dominates the ad, the consumers switch off, however if incorporating an audio jingle and showing product close to the moment of consumption that will work. Along with that, they make a strategic decision to and pause development of any new product and prioritize the supply of their main hero products, such as fish fingers, chicken dippers, chicken grills, peas and potato waffles.

a. Over excited tone of the marketing messages

Desperate to remain relevant at a time when the outbreak was massively curtailing economic activity, many business rushed with the messages classified as "COVID-coping" and "COVID-helping"managing oneself and the pandemic (Hessekiel, 2020). However, excitement driven or scarcity-driven tone (do not miss out, grab this opportunity before it is too late, capitalize this deal, take an advantage of an offer, make the most of this ....) will more likely to characterize business as unaware or ignorant thus not resonate with consumers much (McCormick, 2021). Overwhelmed and stressed-out consumers will remember how certain businesses make them feel in this moment, their stance and tone of the message. "COVID-washing" - where companies put more effort into trying to look empathic than being actual genuine empathic, their focus is to sell and promote their products, shows businesses are struggling with acknowledging the needs of individual, family, and a community in ads, words, pictures on the website, and fundraising appeals (Mckenzie, 2020).

b. Struggle in balancing rational-emotional aspect in marketing messages

Many brand managers had only a superficial understanding of brand values and tended to focus on functional values that others could easily copy (de Chernatony \& Dall'Olmo Riley, 1996). Through the blend of functional and emotional values, it represent the heart and soul of a corporate service marketing (Free, 1996; de Chernatony \& Dall'Olmo Riley, 1999). Previous research also indicated that for crisis communication, brand's emotional and attitudinal factors are more sustainable and should be considered than functional benefits, which may be easily copied (de Chernatony, Harris \& Dall'Olmo Riley, 1999; Jin, et al., 2014; McDonald \& Cokley, 2013). Mensa and Vargas (2020) also revealed that during uncertainty of COVID, a preference for positive emotional appeal (nurturance and affiliation) was used more along with sorrow, nostalgia and excitement. However, identified that an emotionally arousing 
appeal may not always be provide an advantage in remembering the ad's content (Riemer \& Noel, 2020). Criticism also found on the marketing incentive campaign of doughnut to motivate COVID-19 vaccination (Weiner, 2021).

Efficacy of message framing depends on whether the crisis response strategy of organization matches the crisis type or not, incase of high crisis rational framing of crisis communication increase the attitude toward organization (Claeys \& Cauberghe, 2014). Along with that, literature also identified that, it is difficult for consumers to engage with only rational behaviors (mask wearing) concerning the future safety prior to emotional acceptance of the pandemic as an actual threat for life (Robinson \& Versesiu, 2021). Further literature assert that consumer confusion occur if cognitive element is limited and less effort in process of information consumer can fall into stereotype (Mitchell \& Papavassiliou, 1999; Macrae \& Bodenhausen, 2000).

c. Consumer get upset with insensitive and using wrong wordings

Furthermore, to promote social distancing, some brands put a bit of extra distance in their own logos, Mcdonald in Brazil separated its yellow arches, Volkswagen put extra space between the $V$ and the W and Audi logo separates the four rings from each other, but it was not universally lauded (Steinmatz, 2020).

A complain of insensitive and a very badly written reason-to-buy a bread and dough maker was made about a company, Kent healthcare products in India, asked in ad, "Are you allowing your maid to knead the flour dough by hand? Her hands might be infected. Don't compromise on health and purity and buy the Kent Bread maker". The ad was withdrawn and company apologies for hurting sentiments.

Another problem, which was noticed that some brands had jumped on the COVID-19 CSR bandwagon too fast, without thinking through the campaign or the financial implications. The fashion brand Draper James appreciation promotion 'dresses for teachers' backfired as it intended to give-away only 250 dresses, but received over 1 million applicants as they thought teacher who asked for a dress would receive one. Later applicants were deeply disappointed when they learned that was not the case. Not only Draper James failed in delivering on their promise of free dresses, but they also started spamming the same people by emailing them with promotional offers, discounts and trying to sell dresses (Shadani, 2020).

d. Consumers get upset with COVID- surcharges

Businesses need to calm the nerves of consumers by having clear, concise, and accurate message, as the uncertainty can be stressful. Reassure consumers about supply chain robustness may help alleviate panic buying (OECD, 2020). Though noticed that, and Harold's Chicken Shack in Chicago, charge COVID 19 surcharge, it went viral customer were scrutinizing, however restaurant responded that due to increase prices. The Harold's Chicken Japanese restaurant in US Missouri initially added a $26 \%$ surcharge to make up for an increase in supply costs from supplier on meat, poultry, seafood and produce, but after backlash from customers decreased the surcharge to $15 \%$ (Taylor, 2020).

e. Consumer get upset adverting out of stock items

Businesses should also make sure to supply rapid capacity of an items and do not advertise products that may be out of stock. As Lysol disinfect wipes and sprays, ads are under fire since people cannot as easily find these products instore and online, thus consumer consider it insensitive and start complaining on their Facebook page Lysol USA about this issue (Murphy, 2020). Furthermore, to stop multi-stock purchase and panic buying, in Denmark a supermarket charges $£ 4$ for one hand sanitizer and $£ 122$ for two, no one wants to pay £122, this strategy was applauded on their Facebook page and urged other supermarkets around the world to incorporate it (Baker, 2020). Also, ALDI supermarket launched an ad campaign to reassure the buyers that no shortages and their prices are low in COVID aswell.

f. Consumer get upset on kind donation request

Nevertheless, some known and big brand did not realize that the output of their marketing ad would possibly perceived wrongly- such as Airbnb, has managed to spark outrage on social media as they encourage guests to send "kindness cards" to hosts along with an optional monetary donation, even host criticized for this donation request (Dunham, 2020). 


\section{g. Sharing false information}

Businesses should be able to substantiate claims of immunity against or treatment for coronavirus supported by recognised and approved health authorities or regulators. Facebook removed a viral video sharing false information about cure and treatment for COVID-19. In the video claim that the antimalaria drug is a cure for COVID and no mask required. The claims were in contrast to the advice from public health officials to prevent the spread of the virus (Sam, 2020).

h. Misleading advertisement

Ryanair advert faced a complaint by 2,370 viewers' to the Advertising Standards Authority. They reported it as misleading and irresponsible because it encouraged people to believe that once they had even the first vaccination shot they do not need follow restrictions. The ad stated "Covid vaccines are coming so book your Easter and summer holidays today with Ryanair". The ads showed young group of people engaged in activities (jumping in a pool and being served at a restaurant, with no social distancing or use of face coverings). Ryanair justify their ad by stating it was designed to be uplifting and to consider a brighter future (Sweney, 2021).

Another example of KFC UK campaign, which was hastily pulled during struck of coronavirus, because almost 160 consumers 'complained about an ad that revolved around finger licking due to hygiene implications.

Another example, which was pulled on consumers complained and modify it later by adding coronavirus precautions into its commercial - Hershey chocolate company removed human interaction and feature only chocolate bars, text, and voiceover (Wohl, 2020). In addition, Hershey targeted e-commerce shoppers and cut back on large assorted bags of candy in favor of smaller ones during Halloween (Gasparro, 2020). After severe mocking and criticism, silver and gold chainmail facemasks sold for $\$ 17$ were pulled from the ASOS website (British online fashion and cosmetic retailer for young adults).

i. Avoid being tone-deaf

Furthermore, to avoid being tone-deaf, business need to realize which ad they can pulled at such situation such as JP Morgan Chase pulled their credit card ads, also identify what competitors are not doing; it will give a chance to improve their own services and ads.

j. Exploiting fear or xenophobia

Exploiting fear or blame game will not endear business; a restaurant in New Mexico displayed a sign "Blame China" for COVID outside their restaurant doors, faced backlash. Due to racist and xenophobia (dislike or prejudice against people from other countries) reaction to COVID, oldest Chinatown in North America, out of 150 restaurants, only 70 have reopened in that neighborhood (Krader \&Ludlow, 2020).

Negative emotions of audiences and negative publicity will be difficult to remove from the internet, even when a crisis has ended (Baghi \& Gabrielli, 2019; Gonzalez-Herrero \& Smith, 2008). Moreover, the formation of brand equity will be complicated if consumer negative behavior remain (cynical attitude, complaints, negative word of mouth or exiting and switching (Chylinski \& Chu, 2010). In times of crisis, consumer prefer buying familiar and trusted brands, but consumer confusion will exist if they perceive brand similarity, overload information /too many options and ambiguity in product characteristic or advertisements as a result they will postpone their buying decision and possibly effect on their loyalty (Walsh et al., 2007; Mitchell \& Papavassiliou, 1999).

3.11. The theoretical conceptual framework of factors business should be consider to manage and survive the crisis in future

After reviewing the relevant existing literature, this study propose the theoretical conceptual framework, five points (Fig 1), identified as:

a) Clarity and tone of the communication message

b) Overview/review of communication, operational and strategic process of business and measure outcome

c) Be vigilant, identify the risk, vulnerability - refocus on the values of brand

d) Gather intelligent information using analytical tools 
e) Devise appropriate reactive and proactive responsive strategies to survive in uncertain situation Although conversation and connectivity through social media outlets provide new opportunities to engage stakeholders in crisis (Baron \& Philbin, 2009), but it need a braced and balanced strategy. Marketing has emerged as the nerve of a business pandemic response. However, businesses have choice, they can withdraw and go on hibernate until everything get normal or exploit the opportunity or redeem their position based on consumers' circumstances, simultaneously relevant and sensitive. Without sounding opportunistic, businesses must stay close to consumers to understand their priorities and behaviors evolve, even after lifting the COVID restriction: inclusivity, plan better to help people, encourage purposeful purchasing, simplify the shopping journey, collaborate more, and empower employees, (Burton et al., 2020). In respective to that, experience suggest, immediate quickfix solutions (short-term) should be associated with a long-term strategy (BusinessWeek, 30 October 2008). Consequently, businesses should consider generating goodwill along with positive publicity/ community service contribution without any risk of backlash/criticism or further legal restriction.

- Literature review: Crisis will remain crisis if...

- No learning orientation

- No information or surveillance tools

- $\quad$ Focus more on short term quick fix reactive approach

- Less internal capabilities

- $\quad$ All COVID marketing ads look same

- $\quad$ Rhetoric claim

- Claiming more - doing less

- Taking advantage of situation

- Not focusing on contribution

- $\quad$ Tone deaf as products unnecessary advertise

- Unprepared responsive strategies

- Lack of customer insight of consumer mistrust (negative frustrated, confused, unsure, panic, pessimist)

- Similar functional and emotional values

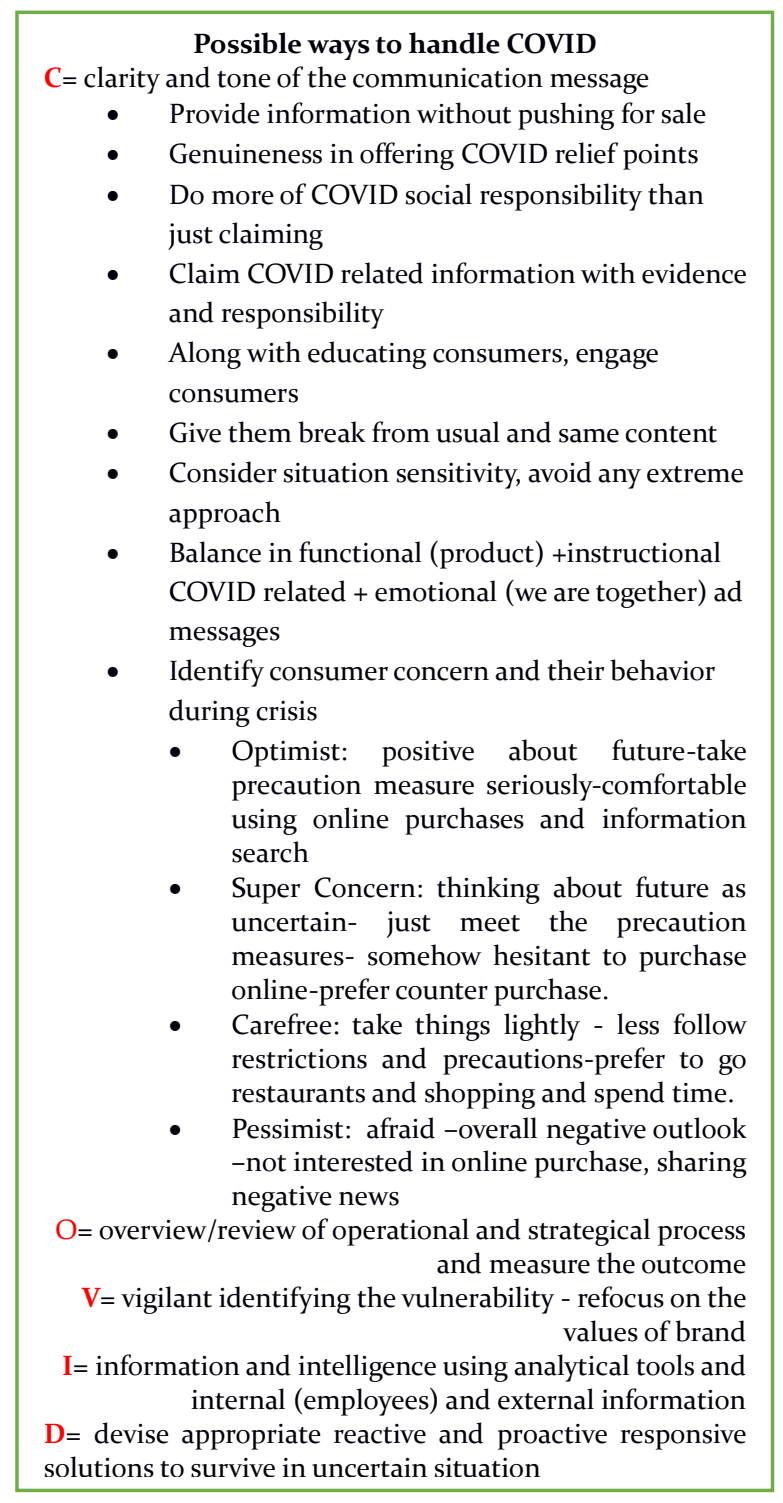

Figure 1. Theoretical conceptual framework 


\section{CONCLUSION}

In order to align organization with pandemic crisis, this research suggest that business need to be alert of their strategic and operational of insights, goals and 'happenings'. Along with emanated solidarity and new normal marketing messages, businesses need to reflect on responsibility through genuine authentic marketing and product solutions. This research conclude that consumer negative feeling toward brand can be reduced if social media communication focuses on emotional and functional values in a balanced way. Lack of information can weakened the resilience and business image of organization. By revisiting, businesses can identify the disruption from the paradigm of target, which will assist in planning reactive and proactive solutions to survive in dynamic yet uncertain market. Analyzing customer behavior and reactions will provide opportunities for rethinking communication, marketing, and product/service portfolios. For survival business need to ensure to utilize the analytics data for further devising responsive strategy and effective communication message.

The limitation of this research is that the presented framework is broad and generic and does not cover all the challenging factors of activities and categories of business of survival during uncertainty. Since, Tafoya (2013) believe that there is no one single best approach to brand crisis management so better to explore more instead of limiting effort. Further empirical research can be conducted to identify and explore other factors that can be critical for survival during crisis.

\section{REFERENCES}

Assiouras, I., Ozgen, O., \& Skourtis, G. (2013). The impact of corporate social responsibility in food industry in product-harm crises. British Food Journal, 115(1), 108-123.

Baghi, I., \& Gabrielli, V. (2019). The role of crisis typology and cultural belongingness in shaping consumers' negative responses towards a faulty brand. Journal of Product \& Brand Management, 28(5), 653-670.

Ball, D., Coelho, P. S., \& Macha's, A. (2004). The role of communication and trust in explaining customer loyalty. An extension to the ECSI model. European Journal of Marketing, 38, (9/10), 1272-1293. http://dx.doi.org/10.1108/03090560410548979.

Baron, G., \& Philbin, J. (2009). Social Media in crisis communication: Start with a drill. Public Relations Tactics, $16(4), 12$.

Buil, I., Martínez, E., \& de Chernatony, L. (2013). The influence of brand equity on consumer responses. Journal of Consumer Marketing, 30(1), $62-67$.

Boksberger, P.E. \& Craig-Smith, S.J. (2006). Customer value amongst tourists: A conceptual framework and a riskadjusted model, Tourism Review, 61 (1), 6-12.

Cheuk, B. (2002). Information literacy in the workplace context: issues, best practices and challenges. UNESCO White Paper, Prague, The Czech Republic.

Chylinski, M., \& Chu, A. (2010). Consumer cynicism: antecedents and consequences. European Journal of Marketing, 44, (6).http://dx.doi.org/10.1108/03090561011032720.

Claeys, A. S., \& Cauberghe, V. (2014). What makes crisis response strategies work? The impact of crisis involvement and message framing. Journal of Business Research, 67(2), 182- 189.

Coombs, W. T. (2006). The protective powers of crisis response strategies. Journal of Promotion Management, $12(3-4), 241-260$.

Coombs, W. T. (2007). Protecting organization reputations during a crisis: The development and application of situational crisis communication theory. Corporate reputation review, 10(3), 163-176.

Coombs, W. T., \& Holladay, S. (2012). The paracrisis: The challenges created by publicly managing crisis prevention. Public Relations Review, 38, 408-415.

de Chernatony, L., Dall'Olmo Riley, F. (1996). Did Brand Managers Ever Jump on the Same Brand Wagon as Brand Consultants? ESOMAR Publication Series, 203, 34-30.

de Chernatony, L., Dall'Olmo Riley, F. (1998). Defining A “Brand”: Beyond The Literature With Experts' Interpretations. Journal of Marketing Management, 14, 417-443.

de Chernatony, L., Dall'Olmo Riley, F. (1999). Experts' Views About Defining Services Brands and the Principles of Services Branding. Journal of Business Research, 46, 181-192.

de Chernatony, L., Daniels, K., Johnson, G. (1993). Competitive positioning strategies mirroring sellers' and buyers' perceptions? Journal of Strategic Marketing, 14, 417-443. 
de Chernatony, L., Harris, F., \& Dall'Olmo Riley, F. (1999). Added value as a Source of Competitive Advantage. Proceedings of the Ninth World Marketing Congress, Malta, June 23-26, 174-177.

de Chernatony, L., McDonald, M. (1999). Creating Powerful Brands in Consumer, Service and Industrial Markets. Oxford: Butterworth-Heniemann.

Denning, S. (2018a). The Age of Agile: How Smart Companies are transforming the Way Work Gets Done, AMACOM, New York.

Denning, S. (2018b). What is Strategic Agility? Forbes. Retrieved from: https://www.forbes.com/sites/stevedenning/2018/o1/28/what-is-strategic-agility/?sh=5azcoeagaob1.

Eater.com. (2020, May 8) https://www.eater.com/2020/5/8/21252241/airplane-food-at-home-delivery.

Eduardsen, J., \& Marinova, S. (2020). Internationalisation and risk: Literature review, integrative framework and research agenda. International Business Review, 29(3), 101-106.

Hessekiel, D. (2020). Lessons From The Early Days Of "Covid-Branding”. Forbes. https://www.forbes.com/sites/davidhessekiel/2020/o8/31/lessons-from-the-early-days-of-covidbranding/?sh=6c6ab9a15c15.

Federal Trade Commission USA FTC.(2021). COVID-19 and Stimulus Reports. https://public.tableau.com/app/profile/federal.trade.commission/viz/COVID19andStimulusReports/Map.

Fine Guard mask. (2020). https://www.fineguard.me/fineguard.

Flammer, C., \& Kacperczyk, A.J. (2015). The impact of stakeholder orientation on innovation: Evidence from a natural experiment. Management Science, 62(7).

Frei, S., Tellenbach, B., \& Plattner, B. (2008). o-day patch-exposing vendors(in) security performance, ETH Zurich, BlackHat Europe.

Fritolay website. https://www.fritolay.com/don-t-miss-your-chance-create-an-ad-and-win-some-cash-withdoritos.

Gonzalez-Herrero, A., \& Suzanne, S. (2008). Crisis communication management on the web: how internet-base technologies are changing the way public relations professionals handle business crises. Journal of Contingencies and Crisis Management, 16 (3),143-153.

Grundey, D. (2009). Branding strategies during Economic Crisis: Avoiding the Erosion. Economics \& Sociology, 2(2), 9-22.

Heath, R. L., \& Millar, D. P. (2004). A Rhetorical Approach to Crisis Communication: Management, Communication Processes, and Strategic Responses. In D. P. Millar \& R. L. Heath (Eds.), Responding to Crisis: A Rhetorical Approach to Crisis Communication (pp. 1-18). Mahwah, NJ: Lawrence Erlbaum Associates.

Heath, R. L., \& Palenchar, M. J. (2009). Strategic Issues Management (2nd ed.). Thousand Oaks, CA: Sage.

Hough, J., Strickland, A.J., Gamble, J.E. \& Thompson, A.A. (2008). Crafting and executing strategy, South African edition, McGraw-Hill.

Jin, Y., Liu, B. F., Anagondahalli, D., \& Austin, L. (2014). Scale development for measuring publics' emotions in organizational crises. Public Relations Review, 40(3), 509-518.

Kalaignanam, K., Kushwaha, T., \& Eilert, M. (2013). The impact of product recalls on future product reliability and future accidents: evidence from the automobile industry. Journal of Marketing, 77(2), 41-57.

Kamber, T. (2002). The Brand Manager's Dilemma: Understanding how advertising expenditures affect sales growth during a recession. Brand Management, 10(2),106-120.

Keller, K.L. \& Lehmann, D.R. (2006). Brands and branding: research findings and future priorities. Marketing Science, 25(6), 740-59.

Kim, S., \& Atkinson, L. J. (2014). Responses toward corporate crisis and corporate advertising. Journal of Promotion Management, 20(5), 647-665.

Kumar, K., Subramanian, R. \& Strandholm, K. (2001). Competitive strategy, environmental scanning and performance: a context specific analysis of their relationship. International Journal of Commerce \& Management, 11(1), 1-13.

Lacey, S., Bruwer, J., \& Li, E. (2009). The role of perceived risk in wine purchase decisions in restaurants. International Journal of Wine, 21, (2), 99-117.

Larkin, J., \& Regester, M. (2005). Risk Issues and Crisis Management: A Casebook of Best Practice: Kogan Page Ltd., London.

Macrae, C. N., \& Bodenhausen, G. V. (200o). Social cognition: Thinking categorically about others. Annual Review of Psychology, 51, 93-120.

March, J.G. (1991). Exploration and Exploitation in Organizational Learning. Organization Science, 2 (1), 71-87.

Martinelli, K. A., \& Briggs, W. (1998). Integrating public relations and legal responses during a crisis: The case of Odwalla, Inc. Public Relations Review, 24(4), 443-465. 
McDonald, L. M., \& Cokley, J. (2013). Prepare for anger, look for love: A ready reckoner for crisis scenario planners. Prism, 10(1), 1-11.

Mckinsey report. (2020). The conflicted Continent: Ten charts show how COVID-19 is affecting consumers in Europe. $\quad$ https://www.mckinsey.com/business-functions/marketing-and-sales/our-insights/theconflicted-continent-ten-charts-show-how-COVID-19-is-affecting-consumers-in-europe.

Miller, D. (1989). Matching Strategies and Strategy Making: Process, Content and Performance. Human Relations, 42(3), 241-260.

Mitchell, V.W. \& Papavassiliou, V. (1999). Marketing causes and implications of consumer confusion. Journal of Product and Brand Management, 8, 319-339.

Narver, J.C. \& Slater, S.F. (1990). The Effect of a Market Orientation On Business Profitability. Journal of Marketing, $54,20-35$.

New Balance. Face mask. https://www.newbalance.com/pd/active-performance-facemask/LAO13099.html.

Arora, N., Charm, T., Grimmelt, A., Ortega, M., Robinson, K., Sexauer, C., Yvonne, S, Whitehead, S., \& Yamakawa, N. (2020, July). A global view of how consumer behavior is changing amid COVID-19. Mckinsey report. https://www.mckinsey.com/ /media/McKinsey/Business\%2oFunctions/Marketing\%2oand\%2oSales/Ou r\%2oInsights/A\%2oglobal\%2oview\%20of\%2ohow\%2oconsumer\%2obehavior\%2ois\%2ochanging\%2oam id\%20COVID\%2019/20200707/COVID-19-global-consumer-sentiment-20200707.pdf.

O'Sullivan, C. (2002). Is information literacy relecant in the real world? Reference Services Review, 30(1), 7-14.

Otamendi, F.J., \& Sutil, M. (2020). The Emotional Effectiveness of Advertisement. Front Psychology, 11.

Rigby, D., Sarah, E., \& Steve, B. (2020). Doing Agile Right: Transformation Without Chaos. Harvard Business Review Press, Boston, Mass.

Rowan, F. (1996). The high stakes of risk communication. Preventive Medicine, 25, 26-29.

Semana.com. (2020). Chocoramo changes its name to encourage Colombians. https://www.semana.com/nacion/articulo/coronavirus-ramo-cambio-el-nombre-de-sus-productospara-apoyar-en-la-cuarentena/667670/.

Souiden, N., \& Pons, F. (2009). Product recall crisis management: the impact on manufacturer's image, consumer loyalty and purchase intention. Journal of Product and Brand Management, 18(2), 106-114.

Srivastava, R., Thomas, G. Managing brand performance: Aligning positioning, execution and experience. J Brand Manag 17, 465-471 (2010).

Strandholm, K. \& Kumar, K. (2003). Differences in environmental scanning activities between large and small organizations: the advantage of size. Journal of American Academy of Business, 3(1/2), 416-421.

Sull, D.N. (2003). Revival of the Fittest: Why Good Companies go Bad and How Great Managers Remake Them; Harvard Business Press: Brighton, MA, USA.

Tafoya, D. (2013). Organizations in the Face of Crisis. Palgrave Macmillan US p. 7-183.

Tenent Research agency. (2020).The Essential Brand Rises: A Time for Brave Brands. USA. https://www.rankingthebrands.com/PDF/Top\%20100\%20Most\%2oPowerful\%2oBrands\%202020,\%20Te net.pdf.

Thorbjørnsen, H., M. Dahlen, \& Y.H. Lee. (2015). The effect of new product preannouncements on the evaluation of other brand products. Journal of Product Innovation Management, 33(3), 342-55.

Tilman, L., \& Jacoby, C. (2019).Agility: How to Navigate the Unknown and Seize Opportunity in a World of Disruption. Missionary.

Vafeiadis, M., Bortree, D. S., Buckley, C., Diddi, P., \& Xiao, A. (2019). Refuting fake news on social media: nonprofits, crisis response strategies and issue involvement. Journal of Product \& Brand Management, 29(2), 209-222.

Waller, M.J.; Lei, Z.; Pratten, R. (2014). Focusing on teams in crisis management education: An integration and simulation-based approach. Academy Management Learning Education, 13, 208-221.

Walsh, G. \& Mitchell, V.W. (2010). The effect of consumer confusion proneness on word of mouth, trust, and customer satisfaction. European Journal of Marketing, 44, 838-859.

Walsh, G., Henning-Thurau, T. \& Mitchell, V.W. (2007). Consumer confusion proneness: Scale development, validation, and application. Journal of Marketing Management, 23, 697-721.

Worley, C. G \& Jules, C. (2020).COVID-19's Uncomfortable Revelations About Agile and Sustainable Organizations in a VUCA World. Journal of Applied Behavioral Science, 56(3), 279 -283.

$\mathrm{Xu}, \mathrm{K} ., \quad \& \mathrm{Li}, \mathrm{W}$. (2012). An ethical stakeholder approach to crisis communication: a case study of Foxconn's 2010 employee suicide crisis. Journal of Business Ethics, 117(2), 371-38.

Zhu, L., Anagondahalli, D., \& Zhang, A. (2017). Social media and culture in crisis communication: McDonald's and KFC crises management in China. Public Relations Review, 43(3), 487-492. 
Vériter, S. L., Bjola, C., \& Koops, J. A. (2020). Tackling COVID-19 Disinformation: Internal and External Challenges for the European Union, The Hague Journal of Diplomacy, 15(4), 569-582.

Mensa, M. \& Vargas-Bianchi, L. (2020). Nurtured and sorrowful: Positive and negative emotional appeals in COVID19 themed brand communications. Journal of Communication in Healthcare.

Robinson, Thomas \& Veresiu, Ela. (2021). Advertising in a Context Harm Crisis. Journal of Advertising. 1-9.

Riemer, Hila \& Noel, Hayden. (2020). The effect of emotionally-arousing ad appeals on memory: time and fit matter. International Journal of Advertising. 1-23. 10.

BBC news. (2020, March 16). Coronavirus: Louis Vuitton owner to start making hand sanitizer.. https://www.bbc.com/news/business-51868756.

Baker, F. (2020, March 22). Supermarket in Denmark charges $£ 4$ for one big hand sanitser and $£ 122$ for two to stop panic buying. Metro. https://metro.co.uk/2020/03/22/supermarket-denmark-charges-4-one-big-handsanitser-122-two-stop-panic-buying-12438078/.

OECD. (2020, April). Protecting online consumers during the COVID-19 crisis. https://www.oecd.org/coronavirus/policy-responses/protecting-online-consumers-during-the-COVID19-crisis-2ce $7353 \mathrm{C} /$.

CNN. (2020, April 13). Rice ATMs' provide free rice for people out of work in Vietnam due to the coronavirus crisis. https://edition.cnn.com/2020/04/13/world/coronavirus-vietnam-rice-atm-trnd/index.html.

O'kane, S. (2020, Apr 15). How GM and Ford switched out pickup trucks for breathing machines. The verge. https://www.theverge.com/2020/4/15/21222219/general-motors-ventec-ventilators-ford-teslacoronavirus-COVID-19.

COVID Youtube video. (2020, April 16). Every COVID-19 Commercial is Exactly the Same. https://www.youtube.com/watch?v=vM3J9jDoaTA.

Ives, N. (2020, April 20).'In These Uncertain Times,' Coronavirus Ads Strike Some Repetitive Notes. Wall street journal. https://www.wsj.com/articles/in-these-uncertain-times-coronavirus-ads-strike-somerepetitive-notes-11587355261.

AirAsia.com. (2020, May 5). AirAsia Delivery Brings In-Flight Favorites to Your Doorstep Order Popular Thai Pearl Tea and Much More. https://newsroom.airasia.com/news/airasia-delivery-stay-home-with-sky-menu.

Taylor, K. (2020, May 5).Wendy's won't switch to frozen beef, even as shortages cause hundreds of locations to run out of burgers. Business insider. https://www.businessinsider.com/wendys-wont-use-frozen-beefdespite-shortages-burger-struggles-2020-5.

Design boom. (2020, May 22). Is burger king handing out giant crowns to ensure social distancing in germany? https://www.designboom.com/design/burger-king-social-distance-crowns-05-22-2020/.

COVID innovation. (2020, June 02). Czech car maker Škoda releases adverts entirely shot from home using toy carshttps://www.COVIDinnovations.com/home/o2062020/czech-car-maker-koda-releases-adverts-entirelyshot-from-home-using-toy-cars.

COVID innovation. (2020, June 11). LUSH invents 'self-timing soap' that dissolves away after exactly 30 seconds of vigorous use. https://www.COVIDinnovations.com/home/o9062020/lush-invents-self-timing-soap-thatdissolves-away-after-3o-seconds-of-vigorous-use.

Ranga, S., \& Tandon, N. (2020, June 15). Misleading Advertisements during COVID-19. Advaya Legal consultancy. https://www.advayalegal.com/blog/misleading-advertisements-during-COVID-19/.

Campaignlive. (2020, June 18). Secret Cinema partners Haagen-Dazs for immersive film nights. https://www.campaignlive.co.uk/article/secret-cinema-partners-haagen-dazs-immersive-filmnights/1680255.

Krader, K., \& Ludlow E. (2020, June 29). After COVID Backlash, U.S. Neighborhoods Rally Behind Chinese Restaurants. Bloomberg. https://www.bloomberg.com/news/articles/2020-06-29/chinese-restaurantsare-making-a-major-comeback-after-coronavirus.

Allison, A. (2020, July 07). Kantar data: stopping advertising will backfire for brands - by Manaswita Singh. Campaign Middle East. https://campaignme.com/kantar-data-stopping-advertising-will-backfire-forbrands-by-manaswita-singh/.

Murphy, S. (2020, July 14). Can't find Lysol disinfectant spray? Here's what to buy instead. USA today. https://www.usatoday.com/story/tech/reviewedcom/2020/o7/14/lysol-disinfectant-spray-hard-findwhere-buy-cleaning-wipes-and-spray/5433716002/.

Dunham, J.(2020, July 16). Airbnb faces backlash after encouraging guests to donate money to hosts. CTVNews. Thursday.

McKenzie, L. (2020, August 19). COVID-19 College Marketing Draws Criticism. https://www.insidehighered.com/news/2020/o8/19/college-advertising-during-COVID-19-drawscriticism. 
Gasparro, A. (2020, Sept 14). Hershey Maps Trick-or-Treating Risks in Hopes Coronavirus Won't Scare Off Halloween Sales. The Wall street Journal. https://www.wsj.com/articles/hershey-maps-trick-or-treatingrisks-in-hopes-coronavirus-wont-scare-off-halloween-sales-1160oog7275.

Al Shehab, N. (2020, October). Does Losing Jobs During COVID-19 Pandemic Affect the Knowledge Management in Businesses?. 17th International Conference on Intellectual Capital, Knowledge Management \& Organisational Learning ICICKM (p. 6).

McCormick, K. (2021, January 22). Marketing During COVID-19: 4 Essential Copywriting Guidelines. https://www.wordstream.com/blog/ws/2020/o4/o2/marketing-during-COVID-19.

Sweney, M. (2021, Feb 3). Ryanair 'jab and go' TV ad banned for encouraging Covid risk-taking. The Guardian. https://www.theguardian.com/business/2021/feb/o3/ryanair-jab-and-go-ad-banned-covid-summerholidays-complaints.

Mistry, B. (1998). Life and soul of the brand. Marketing March, 26, 47-49.

Wohl, J. (2020, 10 March). Hershey pulls ads with hugs and handshakes amid coronavirus concerns.https://adage.com/article/cmo-strategy/hershey-pulls-ads-hugs-and-handshakes-amidcoronavirus-concerns/2243396.

The Guardian. (2020, 30 March). Helmut Marko wanted Red Bull's F1 drivers to deliberately catch coronavirus. https://www.theguardian.com/sport/2020/mar/30/helmut-marko-wanted-red-bull-fi-drivers-todeliberately-catch-coronavirus.

Steinmetz, K. (2020, 2 April). Brands Are Really Going To Be Judged. Companies Are Walking a Tightrope During the COVID-19 Pandemic. TIMES USA. https://time.com/5814509/coronavirus-marketing/

Weiner, S. (2021, 15 April). Dollars to doughnuts: Will incentives motivate COVID-19 vaccination?. AAMC health care. https://www.aamc.org/news-insights/dollars-doughnuts-will-incentives-motivate-COVID-19vaccination.

Shadani, Z. (2020, 27 April).Reese Witherspoon's PR mess is why brands should not force themselves into the COVID-19 conversation. Monday. Arabian Business. https://www.arabianbusiness.com/comment/445773-reese-witherspoons-pr-mess-is-why-brandsshouldnt-force-themselves-into-the-COVID-19-conversation.

Mckinsey \& Company. (2021, May 3). Survey: Chinese consumer sentiment during the coronavirus crisis. https://www.mckinsey.com/business-functions/marketing-and-sales/our-insights/survey-chineseconsumer-sentiment-during-the-coronavirus-crisis.

Mckinsey \& Company. (2021, May 13). Survey: Japanese consumer sentiment during the coronavirus crisis. https://www.mckinsey.com/business-functions/marketing-and-sales/our-insights/survey-japaneseconsumer-sentiment-during-the-coronavirus-crisis.

Taylor, K. (2020, 15 May). People are furious at restaurants adding COVID-19 surcharges, as food prices skyrocket and businesses struggle. Insider. https://www.businessinsider.com/restaurants-COVID-19-surchargesspark-backlash-as-meat-costs-grow-2020-5.

The Mckinsey Report. (2020, 19 May). How restaurants can thrive in the next normal. https://www.mckinsey.com/industries/retail/our-insights/how-restaurants-can-thrive-in-the-nextnormal.

Burton, S. D., Amanda, H., \& Eric, A. (2020, 17 June). The Essential Guide to Post-COVID-19 Consumers. Bain \& company. https://www.bain.com/insights/the-essential-guide-to-post-COVID-19-consumers-video/.

Sam, S. (2020, 28 July) Facebook, Twitter and YouTube pull 'false' coronavirus video after it goes viral. CNBC news. https://www.cnbc.com/2020/07/28/facebook-twitter-youtube-pull-false-coronavirus-video-after-itgoes-viral.html.

Khamis, J. (2020, 12 August). How the coronavirus pandemic is reshaping GCC e-commerce. ArabNews. https://www.arabnews.com/node/1693806/business-economy.

Stewart, T. (2020, 17 August). O2 introduces suite of COVID-19 safety tools for businesses. Mobile Marketing website. https://www.mobilemarketingmagazine.com/o2-covid-19-coronavirus-uk-business-safety-iotbell-integration. 